\title{
BUMIPUTRA AUTHOR'S RESISTANCE TOWARD POLITICAL HEGEMONY AND CANONIZATION OF BALAI PUSTAKA IN THE NOVEL HIKAYAT KADIROEN AND STUDENT HIDJO
}

\author{
${ }^{1}$ Hary Sulistyo \& ${ }^{2)}$ Endang Sartika \\ Universitas Sebelas Maret $^{1}{ }^{1} \&$ IAIN Purwokerto ${ }^{2)}$ \\ mail: harysulistyo123@gmail.com
}

\begin{abstract}
The ideological and aesthetic contestation of Balai Pustaka, forcing writer's resistance particularly Bumiputra writers. The ideological contestation occurs because Balai Pustaka as the apparatus of the Colonial government suppress the resistance attitudes of the indigenous authors. The authors, who ideologically contradicted with the government, resisted the politics of literature through their works. This research is intended to reveal the canonization of Balai Pustaka which governs the aesthetic and ideological standards of literary works and the resistance of Bumiputra authors toward the hegemony of the Dutch East Indies. The method used in this research is descriptive qualitative approach by seeing the text as the representation of hegemony and resistance as well as linking textual and contextual issues to describe literary politics and the reflection of general politics. The objects of this research are the text and historical context represented in the novel Hikayat Kadiroen and Student Hidjo. The results show that Hikayat Kadiroen presents exemplary attitudes of fair leaders in solving peoples' problems and representing the identity of Indonesian literature. Whereas Student Hidjo portrayed concern for the Indigenous people by criticisizing the political hegemony on racial basic. The resistance of Bumiputra authors was shown by raising resistance theme toward colonialism in the Dutch East Indies, as a form of resistance toward political hegemony and canonization of Balai Pustaka.
\end{abstract}

Keywords: hegemony and resistance, Dutch East Indies, cultural identity.

\section{RESISTENSI PENGARANG BUMIPUTERA TERHADAP HEGEMONI POLITIK DAN KANONISASI BALAI PUSTAKA DALAM NOVEL HIKAYAT KADIROEN DAN STUDENT HIDJO}

\begin{abstract}
Abstrak
Kontestasi ideologis dan estetis Balai Pustaka, menghadirkan sikap-sikap perlawanan khususnya para penulis Bumiputra. Pertarungan ideologis terjadi karena Balai Pustaka sebagai apparatus pemerintah Kolonial, menekan sikap-sikap perlawanan pengarang Pribumi. Para pengarang yang secara ideologi berseberangan dengan pemerintah, melakukan resistensi atas politik kesusastraan melalui karyakaryanya. Tujuan penelitian ini mengungkapkan kanonisasi Balai Pustaka yang mengatur standar estetis dan idelogis karya sastra dan perlawanan kelompok Bumiputra terhadap hegemoni yang diterapkan di Hindia Belanda. Metode penelitian ini diawali dengan melihat teks sebagai representasi hegemoni dan resistensi dalam
\end{abstract}


novel Hikayat Kadiroen dan Student Hidjo. Menghubungkan persoalan tekstual dan kontekstual untuk menjabarkan politik sastra dan cerminan politik general. Hasil penelitian menunjukan Hikayat Kadiroen menghadirkan sikap keteladanan pemimpin yang adil terhadap rakyat dalam menyeselaikan persoalan dan merepresentasikan identitas kultural kesusastraan Indonesia. Sedangkan Student Hidjo, menunjukkan sikap kepedulian terhadap Pribumi dengan kritik terhadap hegemoni politik atas dasar rasialis. Resistensi pengarang Bumiputra terhadap Balai Pustaka, ditunjukkan dengan mengangkat tema perlawanan terhadap kolonialisme di Hindia Belanda, sebagai bentuk resistensi terhadap hegemoni dan kanonisasi Balai Pustaka.

Kata kunci: hegemoni dan resistensi, Hindia Belanda, identitas kultural.

\section{INTRODUCTION}

Literature in Dutch East Indies era before Indonesia become an independent nation consisted of Indies Literature, Peranakan Tionghoa (Chinese descent) Literature, Literature of Balai Pustaka, and Sastra Bumiputra. Indies Literature is literary works written by Dutch (Europeans) and their descent who live in the Dutch East Indies which was originally written in Dutch. They wrote their works while visiting or working in the Dutch East Indies. Some of them wondered and fascinated, but some denounced and sigmatized. Indies writers from European descent (not Totok Europeans; totok means native or pristine), often show abigous identity. Regarding with ethical politics, they think that they are better than the Indigenous people since they have European blood (the Netherlands). Ironically, they are not really considered well either by the Dutch or by the Natives. They degrading the Natives, but they are also not considered equal by the Dutch and are seen suspicious by the Natives. One of the Indies author is Louis Couperus with his work $D e$ stille kracht (Occult Science) published in 1900 (Sastrowardoyo,1983:15). The
Dutch Indies era literary has been discussed by Sudibyo (2017). His research discussed about the Uncany, the European-blooded people who had long lived in the Indies like the De Pauly family who felt that the Indies were their homeland and hometown. That kind of experienced is also felt by Sonja, an Indo figure. Despite having gained Dutch citizenship, he decided to visit his native land and commemorate his beautiful childhood in Indonesia (Dutch East Indies).

In order to regulate the literary works written in the Dutch East Indies, the government implemented media politics by establishing Balai Pustaka in 1917/1918. Previously, this institution was named the Commander of the Inlandsce School en Volkslectuur (People's Reading Commission) which was originally founded in 1908 (Rosidi, 1985: 29). This institution was established to provide reading text and book for the people and censoring the publication of literary works in the Dutch East Indies. Balai Pustaka, thereafter, issued Nota Rijnkes; that is a set of rules for censorship provision for any articles and works of art to be published in the Dutch East Indies. 
The main provisions in the Nota Rijnkes oblige that every works should be written in Melayu Tinggi or Riau Malay (which later became the main language of Indonesia/ Bahasa Indonesia) and the text should not contain any elements that are considered oppose to the Dutch political policy. Nontheless, ideologically Nota Rijnkes was used to repress resistance as much as possible to the colonial government especially for the works of art which was written in MelayuRendah as the lingua franka at that time. Thus, authors who understand the political context of Balai Pustaka as ideological censorship opposed and were reluctant to join Balai Pustaka. Notwithstanding, many indigenous authors were affiliated with the colonial publishing organization and achieved success.

Publishing censorship was not merely regulate the literary works but also printed media. The Dutch as the ruler want to control every single work in order not to cause any harm. Therefore, they tried to repress the writers to write any content that consider inappropriate with the Dutch policies. Research on media politics and its correlation with the authorities was once conducted by Anom (2013) who explained that the development of printed media was progressing and reaching the interests of all the people of the archipelago. Not only used for commercial purposes, but also used for political purposes. This situation led the Dutch to create a law that gave severe penalties to those who had the idea of disrupting order in the Dutch East Indies and criticizing the government.

The press of the Dutch East Indies era until the Revolutionary era, faced many suppressive issues as explained by Yuliati (2018) about the relationship between the Indonesian Press and press regulations from the Dutch Colonial period to the Indonesian Revolutionary Period. During this period, the Dutch Colonial Government, the Japanese Military Government, and the Government of Indonesia continued to apply suppressive laws. Nevertheless, the Indonesian Press has always dared to carry out social responsibility in order to achieve a better life and freedom for the nation.

Meanwhile, in term of literary works, Nota Rijnkes of Balai Pustaka at least censors the resistance of two literary groups, they are Peranakan Tionghoa (Chinese Descent) writers who continued to write in Melayu Rendah (Low Malay) until the 1970s and native writers who were incorporated as Bumiputra writers. Some of Peranakan Tionghoa (Chinese Descent) writers who wrote in Melayu Rendah (Low Malay) were Nio Joe Lan, Tio Le Soei, and Tjoa Hin Hoe (Salmon, 1985). Meanwhile Bumiputra writers are native writes who ideologically refused and opposed to the Dutch East Indies government. Some of Bumiputra writers are R.M. Tirto Adisoerjo (Doenia Pertjintaan), FDJ Pangemanan (Tjerita Si Tjonat), Mas Marco Kartodikromo (Student Hidjo), and Semaoen Hikajat Kadiroen (Sumardjo, 2004: 31-32).

Semaoen and Mas Marco Kartodikromo are two examples of the Bumiputra authors who consistently voiced resistance to colonialism. They wrote their works as a form of resistance toward the Dutch East Indies hegemony, both resistance to the Dutch government and the Indigenous 
government in power. Their great are Hikayat Kadiroen and Student Hidjo.

An interesting thing that can be found in the works of Bumiputra, especially Hikayat Kadiroen and Student Hidjo, is the representation of resistance by reflecting the conditions in the Indies era as a form of resistance and concern for the fate of the Indigenous people. Related to the position of Indonesian literature as a representation of Indonesian identity, the recognized convention was more on Balai Pustaka's works which ideologically have political aspects to control the spirit of the movement. Therefore, the thought and representation of the nationalism of the Bumiputra authors is important to be analized in the concept of „Indonesian-ness' (being Indonesian) because historically and geographically, Indonesia and the Dutch East Indies are located in the same land. Wiyatmi, (2003) explained that the pre-independence nationalism was encompasses in Student Hidjo's novel including the rejection of the Dutch government's hegemony by the natives; the love of the motherland and its culture; and distrust of brotherhood offer by the Dutch because of inequality of social strata and position.

This study will draw upon Antonio Gramsci's State and Hegemony Theory. Gramsci explained the features of the theory related to the concept of the state, hegemony, consensus, resistance, and dominance. All those elements are always exist in every country elicited by an irreconcilable historical problem, that is the existence of social class distinction. Gramsci's views on organic intellectuals and traditional intellectuals are important theoretical features to explain the conditions and representations of society reflected in both novels as well as to elucidate SeamoenandMasMarcoKartodikromo position as atraditional intellectual authors.

The purpose of this study is to analyze the expression of resistance in the novel Hikayat Kadiroen and Student Hidjo against the hegemony and the canonization of Balai Pustaka which governs the aesthetic and ideological standards of literary works. It will analyze the attitude of Bumiputra as Indigenous authors who did not accommodate the rules and remained resistant to the Dutch East Indies government even though their works were ultimately black listed.

In addition, this paper is an attempt to deconstruct the historical view of Indonesian literature which generally considers that Balai Pustaka literature was the forerunner of Indonesian literature. Literature censorship is a consensus or even domination of Balai Pustaka, toward Bumiputra authors who represents the struggle and sympathy of the Indigenous people. This paper is expected to renew the understanding that Indonesian literature was not merely Balai Pustaka literature, but it is also necessary to acknowledge the existence of other groups' literature, especially Bumiputra. In addition to the similarity of geographical and historical aspects, Bumiputra authors represented the spirit of nationalism as the begining of Indonesia.

\section{METHOD}

Researchmethodisdefinedastheway to interpret the data based on hypotheses on specific variables (Faruk, 2010). This 
research uses descriptive qualitative methods including descriptions of the text in the novel Hikayat Kadiroen and Student Hidjo as relevant issues to reflect the resistance of indigenous people toward socio-cultural conditions in the Dutch East Indies era. The object of this research are novel Hikayat Kadiroen and Student Hidjo. The data are taken from those two novels supported by other relevant sources such as articles, journals, books and other theories. The descriptive method in this study illustrates textual facts, describing the resistance to cultural hegemony and the political canonization of Balai Pustaka rpresented in the novel Hikayat Kadiroen and Student Hidjo.

The analysis in this study begins with the classification of data based on formal objects in the text which will then be described in tabular form as a result of the research. The formal object is the representation of the conditions of hegemony and resistance in the text which are supported by contextual aspects, namely historical events and other research results. Next, in the discussion section, the correlation between the condition of the text and the assumptions of Antonio Gramsci's theory will be explained regarding hegemony, resistance, and domination.

\section{RESULT AND DISCUSSION}

This section will describe two phases of analysis that is the presentation of results and discussion. The results of this study describe the forms of hegemony and resistance toward the reality in the Dutch East Indies reflected in the novels. Furthermore, the text will be analyzed using Antonio Gramsci's theory and supported with relevant data.
As supporting data regarding the representation of both authors thoughts, their brief profile will be presented to elaborate the collective subject or class they represent. The elaboration of the results and discussion in this study are as follows:

\section{Result}

Concerning the profiles of the two authors, Semaoen was born in Jombang in 1899 and grew in Surabaya. He is a son of a lowly mason employee on the railroad service. Smart and critical in thinking, he has progressive political career at CSI (Central Sarekat Islam), SI (Sarekat Islam), and ISDV (Indische Sociaal-Democraticsce Vereeniging) under Sneevlit nurture in 1915. He was an editor of the Malay language newspaper Sinar Djawa-Sinar Hindia in Semarang besides being involved actively in political parties. Meanwhile, Mas Marco, is a journalist who was raising his journalistic talent in Bandung as a Medan Prijaji journalist.

The description of the textual conditionsinSemaoen's HikayatKadiroen and Mas Marco Kartodikromo's Student Hidjo represented both hegemony and resistance to the Dutch East Indies government. This resistance was not necessarily a form of political resistance to the government system, but also resistance toward hegemoy formed by the Dutch.

The condition of resistance represented in the novels will be ellaborated through text description, then it will be classified into three parts: (a) resistance to Dutch colonialism; (b) to the government system; and (c) to the culture carried out in the Dutch East Indies era. It has relevance to the 
forms of hegemony in that era and to the Nota Rijnkes reflected in both novels. In this case, the resistance is a form of opposition toward the hegemony of the government.

In the novel Hikayat Kadiroen, Semaoen's resistance as an author was reflected in his attitude towards Dutch policies which considered prejudice the Indigenous. The Dutch that was

initially came for trading turned into colonialism. Even when the cooperation with the Indigenous people initially went well, the cultuursteelsel turned unbalanced and made people suffer even more. Hence, that the term cultuursteelsel was more identical to forced cultivation. In this case, the profit-sharing system for farming changed into misery for the farmers. The Impact of Forced Cultivation in the Dutch East Indies, was discussed by Kurniawan (2014), Hermawati (2013), and Zulkarnain (2011) who explained that imperialism was inhumane, impacted peoples' irregular life, and was a brutal system of exploitation and resulted in peasants experiencing poverty and hunger.

The commodity mandatory planting was specifically discussed by Sondarika (2015). First, 32,722 bahu for Sugar (Cane); 22,141 bahu for Tilapia (Indigo); 324 bahu for Tea; 268 bahu for Tobacco; 30 bahu for Cinnamon; and 5 bahu for Cotton. The land used for the system does not cover the entire island of Java. The highest number was in 1845 with 5\% land in Java.

Another form of resistance in Hikayat Kadiroen's novel relates to his criticism of the bureaucratic system is the rule that regulate the ordinary people who want to meet the District Head (camat) must be accompanied by the Village Head. Thus, many people's problems were not resolved properly. In addition, the attitude of the Camat was often arbitrary towards his people which made conditions in the Dutch East Indies even more difficult. Another form of criticism of the complicated bureaucratic system is when the main character reports fraud committed by the Regent. It must go through a resident recommendation before the report reaches the Governor-General.

Priviledge given to Europeans is also criticized by Semaoen in his novels. It is narrated that an Indigenous government employee was so occupied and serious solving the problem when the wife of a Dutch controulur's chicken lost. Ironically, his attitude was reluctant to the report of the Native's Buffalo lost. It is certainly related to the conception of hegemony which gives an exclusive position for Europeans by placing Europeans in the first position.

Another resistant attitude shown by Semaoen in the novel is his criticism of the inability of Amtenaar (Dutch official from the Indigenous group) whose work is to mediate the people and the government. The officials were chosen because of their compliance with the Dutch government. The novel contains criticism that Indigenous officials do not understand the problems of their people. The criticism is portrayed by showing an example of an ideal leader who is able to understand the historical-cultural conditions of his community and is willing to make direct observations to the field as an effort to solve the problem.

The form of resistance related to the cultural aspects in the Dutch East Indies was also reflected in the novel. 
Hikayat Kadiroen shows that feudalism hegemonized thelives of people. Poverty increasing crime and ignorance. Various agricultural and livestock businesses were not successful. The elaboration of these problems on the following table:

Table 1. Representation of problems in the Novel Hikayat Kadiroen

\begin{tabular}{ll}
\hline \multicolumn{1}{c}{ Classification } & \multicolumn{1}{c}{ Resistance Forms } \\
\hline Collonialism & The Dutch did not favour the natives \\
Dutch East Indies & $\begin{array}{l}\text { corrupt bureaucracy, corruption of native officials, Privilege to } \\
\text { European, incompetent Ambtenaar (indigenous employees), Native } \\
\text { officials do not understand the problems of the people }\end{array}$ \\
Culture & Feudalism of native officials, Class hierarchy, ignorance and crime \\
\hline
\end{tabular}

Mas Marco Kartodikromo's resistance in Student Hidjo is criticizing the class hierarchy as a result of colonialism based on racist aspects. Student Hidjo showed resistance toward colonialism in Hidjo's character as an Indigenous youth who was "chased" by Dutch girls. It is an examplary of identity resistance because generally it was the Indigenous women who were being chased and used by the Dutch through an illegal marriage system called gundik (mistresses). This novel, however, narrated a native Dutch girl name Betje being pregnant with Hidjo, an Indigenous man and aborted her pregnancy because she chose to end the relationship.

The resistance to Dutch colonialism is also depicted in the novel, particularly when a native Dutch bellboy received and brought Hidjo's bag when he arrived in the hotel or when a Dutch polished his shoes. It is certainly a serious insult toward the Dutch because in the Dutch East Indies, the Dutch had a high position. Meanwhile, this novel depicting a Dutch become an Indigenous East Indies servant which is contradict with the condition in the East Indies. This novel also illustrates the background of many Dutch soldiers in the East Indies came from the lower classes in the country, inclusind very "dirty" work such as a pig slaughterer. However, they became very arrogant in the East Indies and getting respected by the Indigenous people. The classification of data relating to these problems can be seen on the following table: 
Table 2. Representation of problems in the Novel Student Hidjo

\begin{tabular}{|c|c|}
\hline Classification & Resistance Forms \\
\hline Collonialism & $\begin{array}{l}\text { Dutch women felt in love and used by Hidjo an Indigenous man, } \\
\text { Dutch army parents were a pigmen, Native Dutch as hotel bellboy, } \\
\text { Dutchmen polish Hidjo shoes, Hidjo is dating Dutch women in the } \\
\text { Netherlands }\end{array}$ \\
\hline Dutch East Indies & $\begin{array}{l}\text { Hidjo criticized the organization in the Dutch East Indies, the } \\
\text { occurrence of the SI meeting in Solo }\end{array}$ \\
\hline Culture & $\begin{array}{l}\text { Walter danced Tandak (a traditional dance in Jarak), Wungu refused } \\
\text { to love Walter, Hidjo refused becaming Dutch by marrying a Dutch } \\
\text { woman, arranged marriage }\end{array}$ \\
\hline
\end{tabular}

\section{Discussion}

Representation of hegemony toward the Dutch East Indies in the Novel Hikayat Kadiroen and Student Hidjo

The hegemony representation of the Dutch East Indies era was related to the attitude of feudalism at that time. This attitude caused by the racialist political impacts imposed by the Dutch. As the ruler, the Dutch regulated the rules about caste in society based on race, social position as well as economic aspects. The first position is the Dutch and other Europeans, followed by other Asians, and subsequently the Indigenous people who are divided into Priyayi, including nobles, officials and wealthy merchants. Meanwhile, lowly employees and ordinary people rank respectively in the lowest position. A research about social inequalities related to the aspect of colonialism has been discussed by Farida (2019), regarding the socio-economic inequality of coastal and urban communities in Pramoedya Ananta Toer's novel Gadis Pantai. The research shows the representation of the socio-economic gap between coastal and urban communities in five aspects including; economics, education, environment, social, and culture. Based on these five aspects, the dichotomy was found that coastal communities are represented as poor, ignorant, dirty, insulted and subordinate people. Whereas urban society is represented as noble, smart, rich, respectable, clean, and superior people. It happens because development is only oriented towards cities as the center of human civilization during the colonial era.

The representation of hegemony toward the Dutch government for instance was the establishment of a school for Indigenous nobility as an effort to answer the needs of educated personnel for Dutch institutions. In addition, it is also an effort to give position to the Indigenous ruling class. Indah (2013) explained that there were a number of schools exist at that time including ELS (Europese Largere School), HBS (Hogere Burger School), HIS (Hollands Inlandsche Schoot), and OSVIA (Opleiding School voor Indlansche Ambtenaren).

Political racist has significant impact on the social strata, including the services and administrative processes. Dutch and European have the privilege both in terms of facilities and respect. It was an exemplary form of hegemony created by the Dutch, so that they were respectively entitled by all Indigenous 
people. That model was formed to perpetuate power as an effort to create an integrated community system.

This issue is also reflected in Semaoen's Hikayat Kadiroen. When one of the Dutch East Indies government officials came to a Wedono Assistant office, the attitude of one of the figures in the novel showed hierarchical relationship between two very striking racial groups. Mr. Administrator who is native Dutch, getting more respect from Assistant Wedono and his adjutants. Their attitude is excessive and afraid for being late as in the following quote:

"What is called Opas here is an old man named Pigi. He has worked 33 years as Opas Asisten Wedono Semongan too. He used to get lessons on how to respect all Dutch guests. Especially if the guest is Mr. Administrator. Guests of such high position will definitely be called "Kanjeng" (Lord). Likewise what was ordered by such great guests must be done as soon as possible. Therefore, it is not surprising that Opas Pigi immediately ran away as if cased by a tiger to tell Mr. Wedono Assistant while he was having breakfast in the dining room. When Mr. Assistant Wedono heard the news that Mr. Administrator will come, he immediately stopped eating. He took a suit and went hurriedly like someone who was about to take the train which ready to leave, and ran to the pavilion to meet the great Administrator" (Semaoen, 2014: 9-10)

The above quote shows the attitude of the Indigenous people toward the Dutch in the Dutch East Indies era. Even though the guest was only an Administrator officer, Assistant Wedono's attitude who should have high enough position shows the same attitude as Pigi who was only a messenger. The novel clearly illustrates the Indigenous attitude towards Europeans, especially the Dutch. They seems feared the Dutch and pay exagerated respect toward them because they were hegemonized over racist political policies.

In addition to the above quote, the feudalism hegemony in the Dutch East Indies era was related to racist political policies. It can be seen from the interaction between indigenous officials (ambtenaar) towards people with lower socio-economic strata ${ }^{6}$. In this case, the official occupies the strata commonly referred to as Priyayi shows different attituted towards lower classes society and towards the Dutch.They received respect from the Indigenous people with lower strata status however they tend to look down on them. Ironically, they give exagerated respect toward the Dutch eventhough they are not having higher rank in the society.

The next event was when a man named Soeket filed a complaint over the disappearance of the buffalo stolen by someone. Soeket was accompanied by the Head of the village to the Assistant Wedono office. The Assistant Wedono disrespect his own people because they are from lower social strata as reflected in the bellow:

"Wait for me to eat first" After eating, he called Soeket who immediately explained the matter.

"O, Ndoro, servant of the poor. The servant only has a buffalo, as a pedestal to earn money and rice. But suddenly, last night the buffalo was stolen by someone!" 
"You are very careless! Where did you go all night? Sleep well? that's all you can. Imagine that big buffalo. Stolen by people and you don't know. How lazy you are! Now you ask for my help. Do you really can't maintain your own buffalo? Idler!"Said Mr. Assistant Wedono furiously, Semaoen, $(2014 ; 19)$.

The quote above shows Priyayi's attitude in the context of social life in the Dutch East Indies when he received complaints from his own people. Mr. Assistant Wedono was immediately angry to Soeket without consideration just because he is an ordinary inlander who has lower rank in society. Hikayat Kadiroen's as representation of the conditions of community life in the Dutch East Indies shows priyayi's inverse attitude as a regentwhen facing complaints from Dutch officials and their own people.

The representation of the Dutch East Indies hegemony in the era of Hikayat Kadireon shows in the realisation of how the racist political policies implemented and affected the society from the higest levels to the lowest levels of society. The Indigenous shows an inverse attitude towards Dutch officials by giving title "Kanjeng" as a depiction of high and respected position, meanwhile to the indigenous people, they tend to ignore and degrade them. This difference in attitude shows that Indigenous officials, commonly referred to as Ambtenaar, are afraid to lose their position as Priyayis with all positions they have. They have to be good to the Dutch representation in order to maintain their position and power.

Student Hidjo on the other hand, portraying the form of hegemony towards feudalism of the Dutch East Indies over political racisialist. It can be seen on Hidjo's arrival in Amsterdam and staying in a hotel, he was respected by the waiters because the Dutch think that Indigenous people who come from the Indies, particularly Java were considered rich and noble. It shows that there is binary opposition in the paradigm in the Netherlands and in the Indies regarding hegemony. As far as Hidjo previously understood, the Dutch had a high position and were respected in the Indies. However, based on the narration, what happened in the Netherlands was contradictory. Every Indigenous who came to the Netherlands is also highly respected by the Dutch people because they are considered rich as reflected in the following quote.

"After Hidjo and his leerar got off the ship, they went straight to the hotel. Arriving there, Hidjo was well respected by the waiters. Because they think, if new people come from the Indies, they must have a lot of money. Especially if they are Javanese. Therefore, Hidjo laughed silently at the situation. Because he remembers the fate of his people being humiliated by the Dutch "Kartodikromo (2015: 41).

Based on the above quotation, it can be understood that Mas Marco Kartodikromo's Student Hidjo reflecting that the Indies people should not exagerately glorified the Dutch, because, on the contrary, the Dutch really respect and admire the people of the Indies because of the assumption that the Indies are a wealthy society, especially those visiting the Netherlands. Student Hidjo shows that racist political hegemony 
in the Indies with an excessive attitude in upholding the dignity of the Dutch nation was something that should not have happened. He showed that with the many Dutch people who work in the lower sector, especially for those who live and work in the country.

\section{Resistance toward canonization of Balai Pustaka in the Novel Hikayat Kadireon dan Student Hidjo}

The form of Semaoen's resistance as the author against the Dutch East Indies government was by not accomodating the rules set by Balai Pustaka through its Nota Rijnkes. As explained earlier, Balai Pustaka with its Nota Rijnkes regulates language issues and content that the author should adhere to. Inorder to get their works published by Balai Pustaka as well as to gain popularity and success, the authors were forced to use Melayu Tinggi and were not allowed to criticize the Dutch East Indies government. Thus, the most reasonable form of author's resistance especially for those who were reluctant to support the political concept of the Dutch East Indies government, was by maintaining to use Melayu Rendah (Low Malay) as their media to write their ideas and aspirations both for literary activities and for other writing activities.

The general view on the history of Indonesian literature and the majority of literary researchers consider that Balai Pustaka novels are early Indonesian literary works. It was as stated by Nugraha (2019) who said that Azab and Sengsara and Siti Nurbaja have Indonesian words to help foster a new identity among education and help conceptualize the new idea of homeland. Whilst Student Hidjo and Hikajat Kadiroen do not see beyond the land of Java and they only relate the Dutch East Indies to the land of Java. This opinion seems to override the spirit of "keindonesiaan" in the novel Hikayat Kadiroen and Student Hidjo which is considered only related to the Dutch East Indies and Java. It is not entirely true because class representation in Semaon and Mas Marco is not only exemplify resistant toward the colonial government, but it also shows "beyond Indonesia" as collective ambition to be free from colonialism and social injustice. On the other hand, the existence of Balai Pustaka's works is a reflection of the hegemony of media politics through various ideological and political aesthetic standards.

Ulrich Kratz (2000; 7-8) in his book Sumber Terpilih Sejarah Sastra Indonesia Abad XX explained that the Nota Rinjkes is a set of rules employ by Balai Pustaka in the era of the Dutch East Indiesas an effort of the Dutch Indies Gubermen who wanted Balai Pustaka to only select and publish the literatures and books written in Riau Malay language or later known as Melayu Tinggi. The selected literary works then will be submitted to the comitee and author's hearing. "What they investigated was the content and language of the essay: whether the contents are in accordance with Dutch politics and whether the language is Riau Malay or not?". That statement clearly affirm that Semaoen and other Bumiputra authors, showed resistance to the Dutch East Indies government, especially in terms of media politics by rejecting Nota Rinjkes. In addition, Sumardjo (2004) categorized Semaoen's Hikayat Kadireon 
as part of Melayu Rendah (Low Malay) Literature which certainly did not use Riau Malay. Seeing the contents of the novel in form of storytelling, Hikayat Kadiroen represent Semaoen's thought as a form of criticism to the Dutch East Indies government, particularly for ambtenaars who provided unfair services to the indigenous communities and to the Dutch.

Hikayat Kadiroen is the evidence of the representation of Semaoen's attitude in rejecting the Nota Rinjkes. His sharp criticism of the Wedono Assistant's unfair attitude as well as a "bootlicker" of Dutch officials, reflected his resistance to the social and political conditions at that time. Suyatno, (2016, p. 81-82) explained that in Hikayat Kadiroen, the class conflict almost occurs in the whole novel. In the begining chapters, the condition of colonial birocracy represents capitalism and imperialism that stand for the elite and priyayi rather than to the society are presented to the readers. This problem is reflected in the following sections of the Hikayat Kadiroen novel:

"That's the answer to Mr. Assistant Wedono. He was very rushed and very fast when managing the matter of the administrator, but he ignored Soeket's problem. Even he was told to wait first. This kind of action is not surprising because a social class administrator is the same as an official such as a Resident, Controller, Regen, Patih, and so on. Such great people are very easy to relate to the big gentlemen above and it is easy to complain about the actions of the ambtenars like the Assistant Wedono to the superiors. Conversely, a villager like Soeket, is very difficult to complain about the mistakes of the authorities. While to meet the Assistant Wedono he had to report with the lurah first, let alone if he wants to meet with Mr. Regen or Mr. Controller to report the errors of officials of the Wedono Assistant", Semaoen (2014; 12-13)

The above quote shows ambtenaars' bad behavior often happen in the era of the Dutch East Indies. An Assistant Wedono was described being excessively respectful and obedient to the Dutch officials. Conversely, they become direspectful, arrogance and ignorance toward their fellow countrimen's complain, especially with people who are from lower socio-economic or rank. Semaoen through Hikayat Kadiroen showed a critical attitude and opposed the existence of class hierarchy in the Dutch East Indies on the basis of race and rank issues.

Furthermore, Semaoen described the ambtenaar's attitude as Assistant Wedono with the term foul, Dutch's bootlicker, and was ruthless towards his own people, as a problem that seemed common in the Dutch East Indies at that time.

"That is the character of $\mathrm{Mr}$. Assistant Wedono who is rotten when he responses to the small people's complaint. This kind of Wedono assistant doesn't want to know that he is paid by Gubermen to serve the needs of small people too. He felt himself as a king in front of small people so that the people will constantly afraid of him. By means of this kind of oppression, he tried to make the small people not easily complain about the case they faced. If it happened, that would 
make him do so many works and he has to finish many affairs and that certainly would make Assistant Wedono can not eat well and sleep well. By suppressing the feelings of the people who dare to claim their rights, their orders are easily obeyed by their people. On the contrary, the people became very frightened, and their independence became completely lost, hence people's desire to build up their own destiny became increasingly forgotten. Finally, the people became patient in all things and sothey would continue to be poor ", Semaoen (2014; 20-21)

Thus, it can be seen that an ambtenaar or Dutch official taken from a native, acts like a king and is arbitrary towards his people. Complicated bureaucratic system providing safe conditions when they do not carry out their duties properly in serving the community. In some parts of his novel, Semaon as the author has contrast ideology with the Dutch East Indies government. He is not only resistence to Nota Rijnkes and Balai Pustaka, but also reject the ideology that human can be differenciated according to their social strata.

Furthermore, Mas Marco Kartodikromo's racial based resistance was previously discussed by Tickell (2006; 73), particularly Matahariah. Tickell pointed out that the novels was discussing a good Javanese Assistant Wedono who always defending the local farmers from arbitrary and racist violence of the Dutch plantation foremen. It can be understood that Mas Marco Kartodikromo conveyed criticism of the arbitrariness of ethical politics in the Dutch East Indies, including Java.

Similarly, Student Hidjo also raised criticism of racial issues in the Dutch East Indies. It was narrated when Hidjo and the owner of the house discussed about the issue of skin color and racism as in the following quote:

"Nee, Mevrouw"! If my skin can turn white like a Dutchman, I really like being Dutch, "Hidjo said bravely to the hostess. "But because my skin is bruin (dark red), all right, I'1 just be an Indies." Kartodikromo, (2013; 48).

Based on the above quotation, it can be understood that Hidjo is not questioning whether he is Dutch or Indian. In this context, Hidjo presumptuously conveyed his idea that the difference between the Dutch and the Indies was merely the different in skin color. Thus, apart from these problems, both the Netherlands and the Indies were same and equal without the existence of other hierarchies including social strata or racism which were the products of colonialism.

Mas Marco Kartodikromo through his novel wanted to convey the idea that the problem of racial hegemony established by the Dutch in the Indies should be eliminated, because basically all are human beings who should be able to have equal position despite being different in skin color. That naration can also be seen as Mas Marco's criticism form of the class hierarchy on racial basis. In the context of the Dutch East Indies, Natives such as Marco are humiliated.

In addition, Mas Marco Kartodikromo was an ISDV figure, the forerunner of socialist ideology in the 
Dutch East Indies. In the ideological context, ISDV tends to reject the conception of degrading human dignity based on class hierarchy and racism. Thus, Mas Marco Kartodikromo's works such as Student Hidjo and Matahariah, were used as media of political propaganda against the racialist principle of class hierarchy in the Dutch East Indies.

\section{Socio-Political Context of the Novels Hikayat Kadiroen and Student Hidjo in the Dutch East Indies}

Ideological and national movement in the Dutch East Indies, especially in the establishment of Balai Pustaka era, were indeed quite massive. The establishment of Indische Partij which was founded by some Indo figures such as Edward Douwes Dekker (1912); Budi Utomo (1908); Sarekat Islam (1912); Muhammadiyah (1912) and others. Thus, the spirit of movement influenced the conditions developed in the Dutch East Indies at least beginning in the early 1900s. Those socio-political context was narated clearly in Student Hidjo. The novel describes the congress of Sarekat Islam (SI) in Solo. The history of the national movement was discussed by Imsawati (2017) who explained that the national movement in Indonesia was peoneered by an educated group marked by the establishment of the Budi Utomo organization on May 20, 1908. The national movement could not be separated from ethical political policies and the implementation of colonial education by the Netherlands in Indonesia. Schools founded by the Dutch colonial government contributed to the fulfillment of education in Indonesia. Indonesian children have the opportunity to go to school up to the middle level and even to the tertiary level.

Another factor for the development of nationalism spirit and movement in the Dutch East Indies was explained by Sulistyo (2018) stating that it began with a large number of readings on the interests of the European market and the establishment of indigenous schools for administrative staff as the result of the changes of centralized government system towards decentralization. Many people in the Dutch East Indies were becoming more literate in reading and writing. It introduced Latin scripts in the Dutch East Indies due to the large number of works written by the Dutch, Indo Dutch, and several Indigenous writers on the Dutch East Indies using Dutch. In addition, many translated works from western literature was published in the Dutch East Indies. Specifically, literary works written by the Dutch, Indo-Europeans, and Indigenous people use Dutch about the Indies, referred to as Indies literature.

The massiveimpact of the movement was to voice political aspirations and oppose the Dutch East Indies government in various fields. The large number of newspapers and magazines as media aspirations for voicing people's thoughts made the Dutch East Indies government exercise strict control. No exception in terms of language and content issues as reflected in the Nota Rijnkes, as well as giving legal sanctions for the people who are considered insluting and doing propaganda against the government. For instance, Mas Marco Kartodikromo and Semaoen, both had been imprisoned by the Dutch East Indies government. Their critical 
attitude through their writings which published in the newspapers caused legal case called persdeclit and they were jailed because of that. The problems faced by Mas Marco Kartodikromo and Semaoen were also reflected in Hikayat Kadiroen as a form of reality representation in the literary works era as well as a form of criticism and resistance to the government in the following quote:

"Persdelict. This is the day we have Hoofd-Redacteur called by the attorney in his office and was told that the Assistant Resident told him, the prosecutor, to ask questions about Sinar Ra'jat on the $12^{\text {th }}$ day of May, especially about the articles contained in the day entitled: "Requested a little quickly", and marked by Pentjari. Mr. Prosecutor in addition asked questions about the contents and purpose of the essay, also asked to know the actual author's name, because Pentjari is a fake name. Of course we have Hoofd-Redacteur not like to explain the real name of the requested one and answer that he will bear the essay himself before the court judge if it becomes a claim. According to the prosecutor, the essay must be a legal case, because Mr. Assistant Resident in the city of $\mathrm{G}$, was firm to punish the one who spread the essay. Already the fate of HoofdRedacteur has been hit by a "delict", Semaoen $(2014 ;$ 155).

The above quote represents the conditions occurred and developed in the Indies. It shows how Dutch hegemony employed to regulate content of an essay or literary works circulated in the society through the force of legal action. The essay was considered oppose and contradict to the Dutch ideology and thus endanger their power in the Indies. The government was anxious that such essay would influenced people resistance toward government and lead to uprising movement. Semaoen's Hikayat Kadiroen is the evdience of his resistance toward Dutch political ideology by portraying anti-attitude towards humiliation of human dignity due to social differences.

The Dutch East Indies government domination attitude, as reflected in the quotation above, is the efforts to uphold their hegemony to strengthen the integral state as in Gramsci's perspective relevant to the context of the Dutch East Indies. The efforts of hegemony and exemplary were strengthened through Nota Rijnkes. Authors affiliated with these institutions will publish and distribute their works, especially for schools, so that they can gain recognition, legitimation and economic benefits.

The existence of authors who are not affiliated with Balai Pustaka with their various works and medias will encounter logical consequences of their political attitude. Many Indigenous writers who choose not to follow the rules of Balai Pustaka will be imprisoned and encounter legal action for their works. As an example, Semaoen has to be imprisoned for his writing published in one of the newspapers. His novel protrayed the legal issues used by the government to regulate author's resistance.

The Dutch East Indies Government was aware of potential hazards in the dynamics of the community. The canonization of Balai Pustaka was 
adopted from the regulation employed in India as one of British colonial territories. Reading skills possessed by the people, high reading interest, and the absence of strict supervision, became a serious issue threatening the government in India. Furthermore, the Dutch East Indies government responded to this and made a set of rule known as Memorie van Toelichting (Certificate) $^{8}$.

The rapid growth and development of social and political conditions in the Indies changed the government system from centralized to desentralized. In order to realized that, the Dutch need Indigenous people as government representative in the regions. The government, thus, inisiating the establishment of Dutch schools for Indigenous people with an initial orientation; creating literate society. Schools were specifically intended for upper class society as candidates for government employees. In actually, provides more opportunities for Indigenous people to create other activities in the form of critical thinking and against the government.

The correlation between literature and politics or what is known as political literature portrayed strong in both novels. Specifically in Student Hidjo's novel, propaganda were narrated to increase the spirit of nationalism on the basis of humanity. The role of literature in the era when the novel was published has significant impact on the national movement particularly in gaining public sympathy. Moreover, ideologically Mas Marco is an ISDV figure who is certainly contradicting with the colonialism principles. Anhari (2016) in his research explained that language activities cannot be separated from communication activities. The writing of literary works is sometimes intended to instill the influence as the author wishes. Such activities can be said as propaganda media.

Hikayat Kadiroen and Student Hidjo portay resistance attitude to the colonial government as well as proposing ideological concept of good governance for the progress of conditions in the Indies. The main problems raised by Semaoen in the novel Hikayat Kadiroen relate to the concept of leadership and efforts to alleviate poverty. Leadership is described through the potrayal of Kadiroen in pursuing career from a Police Mantri to finally become Wedono and Patih. It shows that Kadiroen had strong character as a leader. Pujiharto (2014) explains that this is one of the characteristics of pre-Indonesian (beyond Indonesia) literary works which shows that pre-Indonesian identity has a relationship with author resistance.

The relevance of Antonio Gramsci's theory to this research is in the context of the Dutch East Indies, the colonial government applied the rules in the Nota Rinkes which could be interpreted as state hegemony towards the writers. The moral attitude shows that only works published by Balai Pustaka can be said to be quality works. This attitude is intended to suppress the spirit of the Indigenouspeople, especially Bumiputra authors who keep writing their works in Melayu Rendah (Low Malay) and still raised the issue of nationalism and resistance to the government. Domination and consensus were seen in the attitude of the Colonial government in labeling readable works as well as the distribution of works published in Balai 
Pustaka and initiated by consensus by selection process in terms of language and content. Negotiation efforts in this policy is mean to achieve the concept of integral state by uniting every class.

Authors and literary works at that time had an important role particularly because literary works can be seen as propaganda media. Hence, Balai Pustaka realized the need for policies that benefited the Dutch East Indies government. The author as traditional intellectual must be directed as not to create uproar and spirit of resistance which further will complicate the hegemony of the Dutch East Indies government. Resistance showed by writers and society in general must be balanced with policies to regulate interclass relations.

\section{CONCLUSION}

Semaoen and Mas Marco Kartodikromo are Bumiputra authors who chose to be resistant to the Dutch East Indies government. Their works can be seen as the representation of literary politics towards colonialism, particularly rejecting the political hegemony at that era and the canonization of Balai Pustaka to suppress the freedom of expression and resistance on media.

Semaoen's Hikayat Kadiroen resistance toward the Dutch hegemony can be seen from the Dutch attitude who degrading the Indigenous people, bureaucratic corruption, and the incompetence of Indigenous officials. Through the novel, Semaoen exemplifies that a good leader should observe the people dirrectly to ensure their conditions. Mas Marco's Student Hidjo resistance toward the class hierarchy based on racial aspects and political dynamics in the context of the movement, specifically the representation of the Syarikat Islam congress in Solo.

The Dutch East Indies literature as part of Indonesia's past is an interesting representation seen from the textual problems and representations of real life that can be taken as exemplary wisdom. Literary works are reflection of the identity and cultural representation of the Indonesian people as an affirmation of a national identity. Pre-Indonesian literature, particularly Bumiputera can be seen as representation of "beyond Indonesia" today. It is certainly different from the general view that modern Indonesian literature begins with the publication of Balai Pustaka's works.

\section{REFERENCES}

Anhari, A. F. (2016). TeknikPropaganda dalam Novel Student Hidjo Karya Mas Marco Kartodikromo. Skripsi. Kediri: Universitas Nusantara PGRI.

Anom, E. (2013). Regulasi dan Kebijakan Media Cetak di Indonesia Masa Zaman Penjajah. Jurnal Komunikologi, 10(2), https:// ejurnal.esaunggul.ac.id/index. $\mathrm{php/Kom/article/view/1063.}$

Farida, N. \& Andalas, E. F. (2019). Representasi Kesenjangan SosialEkonomi Masyarakat Pesisir dengan Perkotaan dalam Novel Gadis Pantai Karya Pramodya Ananta Toer. Kembara: Jurnal Keilmuwan Bahasa, Sastra, dan Pengajarannya. 5(1), 7490.DOI:https://doi.org/10.22219/ kembara.v5i1.7447.

Faruk. (2010). Pengantar Sosiologi Sastra. Yogyakarta: Pustaka Pelajar. 
Kratz, U. (2000). Sumber Terpilih Sejarah Sastra Indonesia. Jakarta: KPG.

Hermawati, M. (2013). Tanam Paksa sebagai Tindakan Eksploitasi. Avatara, e-Journal Pendidikan Sejarah. 1(1), 64-70. https:// jurnalmahasiswa.unesa.ac.id/ index.php/avatara/article/ view/1123/82.

Indah, W., Maskun., M, Syaiful. (2013). Kebijakan Pemerintah Hindia Belanda Mengenai

Pendidikan bagi Kaum Bangsawan di Indonesia Tahun 1900-1920. Pesagi, Jurnal Pendidikan dan Penelitian Sejarah. 1(2). http://jurnal.fkip. unila.ac.id/index.php/PES/ article/view/476/310.

Ismawati, D. N., Handayani, S., Sumardi. (2017). "The Intelectual's Constribution In The National Movement of In Indonesian 19081928". Jurnal Historica. 1(2), 2252-4673. https://jurnal.unej. ac.id/index.php/JHIS/article/ view/6440.

Kartodiromo, M. M. (2013). Student Hidjo. Yogyakarta: Narasi.

Kurniawan, H. (2014). Dampak Sistem Tanam Paksa terhadap Dinamika Perekonomian Petani Jawa 18301970. Socia, Jurnal Ilmu-Ilmu Sosial. 1(2), 163-172. DOI: https://doi. org/10.21831/socia.v11i2.5301.

Mujiyanto, Y \& Fuadi, A. (2014). Kitab Sejarah Sastra Indonesia. Yogyakarta: Penerbit Ombak.

Nugraha, D \& Suyitno. (2019). On the Biginning of Modern Indonesian Literature. Humanities \& Social Sciences Reviews. 7(6), 604-616. DOI: $10.18510 /$ hssr.2019.7691
Patria, N \& Arif, A. (2015). Antonio Gramsci Negara \& Hegemoni. Yogyakarta: Pustaka Pelajar.

Pujiharto., U, Wening., \& Amini, M. (2014). Identitas Pra-Indonesia dalam Cerita- Cerita Pra-Indonesia. Litera, JurnalPenelitian Bahasa, Sastra, dan Pengajarannya. 13(2), 277-292. DOI: https://doi.org/10.21831/1tr. v13i2.2581

Rosidi, A. (1986). Ikhtisar Sejarah Sastra Indonesia. Jakarta: Pustaka Jaya.

Salmon, C. (1985). Sastra Cina Peranakan dalam Bahasa Melayu. Jakarta: PN Balai Pustaka.

Sastrowardoyo, S. (1983). Sastra Hindia Belanda dan Kita. Jakarta: PN Balai Pustaka.

Semaoen. (2014). Hikayat Kadiroen. Bandung: Sega Arsy Khazanah Pemikiran Progresif.

Sondarika, W. (2015). Dampak Cultuurstelsel (Tanam Paksa) bagi Masyarakat Indonesia dari Tahun 1830-1870. Jurnal Artefak, 3(1). DOI: http://dx.doi.org/10.25157/ ja.v3i1.337.

Sudibyo. (2017). Stereotipe dan Ambivalensi Sosok Bumiputra dalam Novel Kolonial Belanda. Dalam Mencari Formula Baru Kritik Sastra Indonesia. Yogyakarta: Interlude \& YASAYO.

Sudibyo (2017). Uncany dan BayangBayang Koloni dalam Novel Poskolonial Hindia Belanda. Litera, Jurnal Penelitian Bahasa, Sastra, dan Pengajarannya, 16(2), 217-227. DOI: https://doi.org/10.21831/ltr. v16i2.15587.

Sulistyo, H. (2018). Kondisi Bahasa dan Sastra di Era Penjajahan sebagai Refleksi Implementasi UndangUndang Kebahasaan Republik 
Indonesia. Prosiding Seminar dan Lokakarya Pengutamaan Bahasa Negara Lanskap Bahasa Ruang Publik: Dimensi Bahasa, Sejarah, dan Hukum.

Sumardjo, J. (1992). Lintasan Sastra Indonesia Modern Jilid I. Bandung: PT. Citra Aditya Bakti.

Sumardjo, J. (2004). Kesusastraan Melayu Rendah Masa Awal. Yogyakarta: Galang Press.

Suyatno. (2016). Corak Realisme Sosialis dalam Hikayat Kadiroen Karya Semaoen. Jurnal Avatisme. 19(1), 75-87. DOI: https:// doi.org/10.24257/atavisme. v19i1.175.75-87.

Tickell, P. (2006). Cinta di Zaman Kolonial Ras dan Roman dalam sebuah Novel Awal Indonesia. Dalam Clearing A Space Kritik Pasca Kolonial tentang Sastra Indonesia Modern. Jakarta: Yayasan Obor Indonesia KITLV- Jakarta.

Wiyatmi. (2003). Nasionalisme Prakemerdekaan dalam Novel Student Hidjo Karya Mas Marcokartodikromo (Kajian Sosiologi Sastra). Litera, Jurnal Penelitian Bahasa, Sastra, dan Pengajarannya, 2(1), 31-42. DOI: https://doi.org/10.21831/ltr. v2i1.6782.

Yuliati, D. (2018). Pers, Peraturan Negara, dan Nasionalisme Indonesia. Jurnal ANUVA, 2(3), 253272. DOI: $10.14710 /$ anuva.2.3.253272.
Zulkarnain. (2011). Dampak Penerapan Sistem Tanam Paksa bagi Masyarakat. Informasi, Kajian Masalah Pendidikan dan Ilmu Sosial, 37(1), No 1, 57-71. DOI: https:// doi.org/10.21831/informasi. v1i1.4463.

Website

InHistoriamagazine, ed26Agustus2017, explained that Semaun was born in 1899 in Curahmalang, Mojokerto, Jawa Timur https://historia.id/ persona/articles/semaun-dansneevliet-kisah- persahabatan-duaorang-revolusioner-P9jY

Tempo in the National Press Day edition on February 9, 2017, raised the profile of Mas Marco Kartodikromo as a press figure in the colonialerahttps://nasional.tempo. co/read/845647/profil- marcokartodikromo-jurnalis-pergerakanera-kolonial $/$ full \&view $=$ ok

According to Wikipedia, in a nationally agreed size, one bahu is 500 tiles https://www.google.com/search?q $=$ tanah $+1+$ bahu + berapa + hektar $\&$ oq $=$ tanah $+1+$ bahu + berapa + h ekta r\&aqs $=$ chrome. .69i57.5100j0j7\&so urceid $=$ chrome $\& i e=U T F-8$ 